\title{
PSA Level Zero to Two
}

National Cancer Institute

\section{Source}

National Cancer Institute. PSA Level Zero to Two. NCI Thesaurus. Code C153410.

A blood concentration of prostate specific antigen between $0 \mathrm{ng} / \mathrm{mL}$ and $2 \mathrm{ng} / \mathrm{mL}$. 